\title{
Self- Identity and Black American Community in Toni Morrison's Beloved
}

Edging into life from the back door..Becoming.Everbody in the world was in a position to give them orderes.White women said, "Do this". White children said. "Give me that". White men said, "Come here."Black men said, "Lay down". (Toni Morrison)

\section{Dr.Sharda Singh and Dr.Priti Bhatt \\ Department of English \\ Govt.Nirbhay Singh Patel Science college.}

\section{Abstract------}

Independent and integrated identity is coveted by every human being. Each one longs to be called an intelligent, aware, talented, responsive and creative individual. Black men and women are no exception . The two needs of home and wholeness; for which they yearn; are not available to them on this earth. And they lose in the game of searching identity. But it is well said that EVERY CLOUD HAS A SILVER LINING. The present article pinpoints self-esteem and desires of the identify as the core of her protagonists. Sethe,protagonist of the novel Beloved prefers to kill her daughter rather than to re-slave her. Sethe finds that the prevailing definitions of women,mother and wife are challenged by her racist masters...but it is SHE WHO EXERTS HER IDENTY BY PAVING THE TORTOUS PATH..AND REFUTES ALL OBSTACLES WHICH she was sure that being black and women she can never get love and status.

\section{Introduction}

Literature is an account of the feelings of people. These feelings are an outcome of social , political, economic and personal commitments. In this way history of Afro- American relations enforce black people to fight against victimisation. Contemporary literature manifests the feelings, pains and sufferings and stinging stories of victimisation of black community against injustice towards them. Toni Morrison, as a black feminist, led a crusade against the atrocities against black women...who were triply oppressed. Their soul and psyche were completely crushed under the predominant patriarchies. Besides, the pangs of racism and sexism had badly jeopardized their identity.But life is not constant. Life is ever-moving. The staunch supporter of women's welfare, Morrison, contributed consistently. With her perseverance and patience she overturned the traditionally rooted wrong values against black women. Through her novel she portrayed the empowered protagonists who marched ahead for their individuality, identity and self empowerment.

Toni Morrison is the best among the black women writers. That is why, we find that Morrison has always tried to capture the feelings, the gestures, the values and the memories that mould the African American culture. She wants blacks to stand straight and speak fearlessly. Leading feminist writers like Margaret Walker, Rosa Guy, Sarah Wright, Alice Walker, Gloria Naylor, Gayl Jones and Toni Cade Barbara, Toni Morrison tried to discover the hidden truth in themselves and struggled to establish the worth of "self "in the white dominated society.

Toni Morrison in her prize winning novel titled Beloved depicted personal growth and development of the protagonist Sethe. Despite the oddities of of racism and sexism, Sethe began a normal life at her Sweet Home.There she is a slave worker and her master is very kind and considerate. Contrary to her, mother was repeatedly raped and tortured and ultimately hanged. It had casted a terrible and negative impact on her and she became extremely possessive for her children culminating in the murder of her own daughter whom she tried to save from the terrible experiences of being a 'chattel' a slave. She was so terrified with the idea of re- enslavement that she didn't hesitate to kill her own child. A critic of the works of Morrison talks "How much a woman could love in a sacrificial way of how a woman could place the value of her life in a something other than herself"( Naylor 584)

Fragmentation of Sethe's personality begins with the coming of school teacher and his nephews as masters. "They make a choke Cherry tree on her back by a cow hidewhip(Beloved 21) steal her milk meant for her baby daughters(Beloved 20). Unlike Celie of Colour Purple by Alice Walker Sethe didn't get dwarf or maim by black as wife or mother but her situation got worse by racist masters. The school teacher asks his nephews to " put her human characteristics on the left or animal ones on the right". (237)

Generally it is said that 'self help is the best help' and in this context it must be said that Morrison has pointed out the potentiality of each black female who knew how to gain their identity. Sethe is not an ordinary woman. When she knew that her husband is only symbolic male for her, she leaves Halle behind and considered him to be dead because he has failed to protect her milk and as a husband who fails to protect his wife is no husband . 
Morrison has unhesistantly empowered her black protagonist who rejected traditional husband and consciously questioned the ideological code of married life. The writer examines the sensibilities of her protagonist against rigid interpretation of marital codes. So, the writer aptly enumerates the ways in which the oppressed black females react to troublesome situation which caused their fragmentation. Sethe's ordeal did not get over. After escaping from her husband, she was feeling bewildered and loitered homelessly for 28 days and gradually began to mend. Thereafter she faced another set back when she killed her child to protect her from the slave master. She was jailed. On her release, instead of feeling broken she emerged as a determined woman who felt no guilt for her act. She ,believed "I took and put my babies where they would be safe.(201) On her return from the jail she took a job.

During slavery the resistance of black woman against operation was in various ways. While pretending to be genial, many use strategies like poisoning masters, breaking tools and feigning illness an ignorance to avoid work. Some advocated hiding trueselves for their own advantages. Morrison with the fictional situation insisted the role of community sisters which is pertinent in the development of a character. Sethe, who abandoned husband was a tactful lady.She knew that pride hampers relationships. When she was haunted by her ghost-, daughter, it was her second daughter Denver who manipulated to liberate her mother with the help of her community .All the women of community commented "she was trying to do it all alone with her nose in the air"(312). It is with Denver's effort that Sethe is brought back to the fold; she regains her stability.Morrison develops an understanding that a woman can become a best friend which helps Sethe to affirm 'self'.

Her mother-in -law known as Baby Suggs, is compared to Eva and Pilot.She wants people of her community to spend life with dignity.To create the self- confidence she provides her people by saying.

Love you hands, love raise them up and kiss them. Touch others with them.....you got to love it, you. (Beloved 88) She repeatedly advised Sethe to "lay 'em (terrible memories of the past) down; Sethe, sword and shield" (Beloved105)

Morrison's view is that a woman should be connected with the community while battling with the problems of life it leads to move through a process of intensive introspection after facing outer chaos . Internal turmoil makes her crying till certain time, but ultimately it pur- gates and chastises her soul which leads to visualise an essential ingredient of the self. Like other black writers Morrison presents that protagonist rises from nothingness to the position of self empowerment.Sethe is different from others as she has liberated herself from many fold troubles.Sethe regains her peace and felt stable after her team support.Toni Morrison's fictions can be explored for feminist approaches though she never has been a flag holder in any feminist movement nor has she ever advocated any feminist attitude or ideologies. But Morrison strongly propagates the need to reveal against the oppression while doing so she wanted to be careful that is why her family approach evolves through different characters and diversified themes as it is quoted by (Denard), the lead critic.

"black women are much more suited to aggressiveness in the more that feminist are recommending, because they have always been mother and I,abour mother and worker.

\section{Conclusion}

It is said that "united we stand divided we fall". The established author is a humanist too besides being an author.She believed that male and female are compliment to each other. They cherish joys and sorrows together and standby together. So, Se the is made aware that as an outsider, with a destiny in isolation,she cannot succed.The protaganist's life is fully aware that unity and community has strength. Along with the painful coloration of black women Morrison will fully visit them to know their real self to establish their self and to exert their self. This positive attitude may only fruitfully accomplish their struggle for self realisation. Sethe affirms herself by saving the life of a child likewise other black woman she understood her own strength and weakness and they spread the message of love and respect towards all for their quest of identity. Toni Morrison softly speaks that aimless rebellion or infanticide or suicide is not a solution to any problem. She forcefully conveys that it is necessary to face the pain, to give abrave fight against it and move past it.

\section{Work -cited}

Morrison, Toni The Beloved, A Casebook-Andrews-cited by 89.

"The Interview" The New York Republic21 March,1981.

Naylor,Gloria, "A Conversation : Gloria Naylor and Toni Morrison."The Southern Review,211985):567-93

Web-source sites.google.com-academic-essays

Denard .C.Carolyn ----- Literary Conversation Series www.amazon.in 


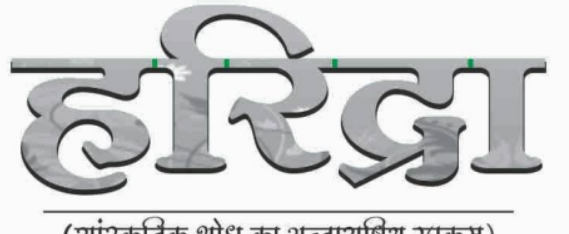

(सांस्कृतिक शोध का अन्ताराष्ट्रिथ उपक्रम)

\section{आग्गह लेखकों से :-}

• शोध पत्र में शीर्षक, नाम, पद, पदस्थापना का विवरण, पत्र व्यवहार का पता तथा दूरभाष क्रमांक, मोबाइल नं. ई-मेल एड्रेस अपेक्षित है।

- शोध पत्र के प्रारम्भ में कम से कम 50- 100 शब्दों का सारांश दिया जाये।

• मुख्य शब्द सांराश के नीचे रहना चाहिए।

- शोध पत्र में शोध पद्धति तथा शोध में प्राप्त तथ्यों का विश्लेषण किया जाना चाहिए।

• शोध पत्र में निष्कर्ष और अंत में संदर्भ ग्रंथ सूची दी जाये। संदर्भ ग्रंथों का विवरण पूरा दिया जाये।

- लेखक का नाम, वर्ष, पुस्तक का नाम, प्रकाशक का विवरण, प्रकाशक का स्थान और पृष्ठ संख्या आदि का विवरण दिया जाना चाहिए।

- शोध पत्र माईक्रोसॉफ्ट वर्ड की फाइल में टाइप किया हुआ होना चाहिए। (नोट- पेज मेकर की फाइल, पी डी एफ . फाइल , स्कैन मैटर आदि में शोध पत्र न भेजें) शोध पत्र हिन्दी / संस्कृत लिपि में कृतिदेव (फॉन्ट साइज 14 ) में भेजा जाना चाहिए, और अंग्रेजी में फॉन्ट एरियल (फॉन्ट साइज 14 ) में भेजा जाना चाहिए।

- शोध पत्र के साथ यह घोषणा अवश्य संलग्न करें कि शोध पत्र मौलिक है तथा इसे कहीं अन्यत्र प्रकाशनार्थ प्रेषित नहीं किया गया है।

- शोध पत्र ई-मेल द्वारा भेजें- haridra5@outlook.com

- शोध पत्र की स्वीकृति की सूचना सम्पादक कार्यालय द्वारा लेखक को ई-मेल एवं दूरभाष द्वारा प्रदान की जाती है।

- रिसर्च जरनल में प्रस्तुत किये गये विचार और तथ्य लेखकों के हैं, जिनके विषय में रिसर्च जनरल हरिद्रा के सम्पादक मण्डल, प्रकाशक तथा मुद्रक उत्तरदायी नहीं हैं। रिसर्च जनरल के सम्पादन एवं प्रकाशन में पूर्ण सावधानी रखी गई है, किन्तु किसी त्रुटि के लिए हरिद्रा रिसर्च जनरल का सम्पादक मण्डल, प्रकाशक तथा मुद्रक उत्तरदायी नहीं हैं। सम्पादन का कार्य अव्यावसायिक और ऑनरेरी है। सभी विवादों का न्यायालय क्षेत्र, इन्दौर जिला इन्दौर (म.प्र.) रहेगा।

\section{Request to Authors}

General: This is Multilingual Research Journal hence research papers can be sent in Hindi, Sanskrit or English. Manuscript of research paper: It must be original and typed in double space on the one side of paper (A-4) and have a sufficient margin script should be checked before submission as there is no provision of sending proof. It must include Abstract, Keywords, Introduction, Methods, Analysis, Results and References. Hindi/Sanskrit manuscripts must be in Kruti Dev 010 font, font size 14 and in double spacing. All the manuscripts should be in two copies. soft copy of manuscripts should be in Microsoft word Format font Arial and font size 14. Authors are solely responsible for the (actual accuracy of their contribution)

References : References must be listed cited inside the paper and alphabetically in the order-Surname, Name, Year in bracket, Title, Name of book, Publisher, Place and Page number in the end of research paper.

Review System: Every research paper will be reviewed by members of reviewer Board. The criteria used for acceptance of research papers are contemporary relevance, contribution to knowledge, clear and logical analysis, fairly good English, sanskrit or Hindi sound methodology of research papers. The Editor reserves the right to reject any manuscript as unsuitable in topic, style or form without requesting external review. 


\section{ध्येय पथ के निर्माता...}

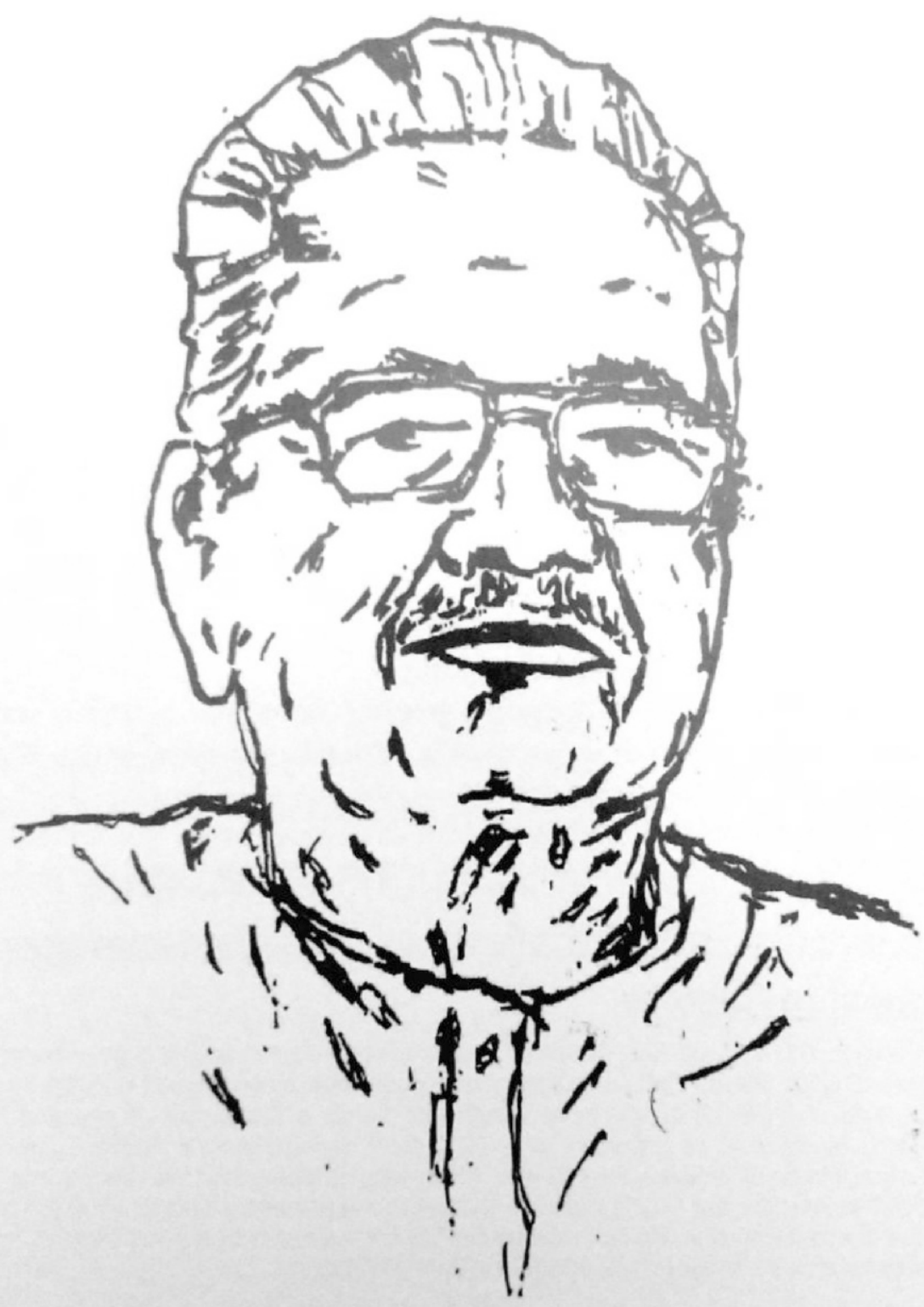

महोपाध्याय आचार्य गणेशदत्त जी त्रिपाठी

(२६ नवम्बर, १९३०-१ अप्रैल २०१२)

स्वामी, मुद्रक, प्रकाथक अभिजीत त्रिपाठी द्वारा टी.एन. ट्रेडर्स प्लाट ने 7 ग्राम अवरासला सांवेर रोड़ इंदौर से मुद्रित एवं 318 प्रोफेसर कॉलोनी टॉवर स्केयर सपना सठवीता रोड़, इंदौर 452001 से प्रकाशित। सपादक - अभिजीत ल्रिपाठी मोबा. 9755091128 